\title{
IMIDAZOLIUM YLIDES: CYCLOADDITION versus HYDROLISIS
}

\author{
DUMITRELA CUCU, ${ }^{\mathrm{a}, \mathrm{b}}$, VIOLETA MANGALAGIU, \\ DORINA AMARIUCAI-MANTU ${ }^{a}$, VASILICHIA ANTOCI \\ IONEL I. MANGALAGIU
}

\begin{abstract}
Reactions of imidazolium ylides with dimethyl acetylenedicarboxylate in polar solvents (methanol) were studied. In the competition between cycloaddition versus hydrolysis, the last one prevails leading to base heterocycle, diene structures and benzoate esters. A feasible reaction mechanism is presented. When fused pyrrolo-imidazole derivatives are desirable to be obtained, polar solvents should be avoided.
\end{abstract}

Keywords: imidazolium ylides, hydrolysis, cycloaddition, reaction mechanism, diene, pyrrolo-imidazole derivatives

\section{INTRODUCTION}

Imidazole derivatives are indispensable structural scaffolds of substantial interest in both academic and industrial research. This five member ring azaheterocycle is considered to be one of the most vital heterocyclic scaffold found in a large number of natural products and pharmacologically active compounds, having a wide range of interesting biological activities, for example, anti-HIV [1,2], antimicrobial (antibacterial, antimycobacterial, antimycotic) [3-7], anticancer [6-8], anti-Alzheimer [9-11], antidepressant, analgesic, antihypertensive, antioxidant, anti-inflammatory [10,11].

Despite of their huge importance from pharmacological, industrial, and synthetic points of view, there are only a limited method for the synthesis of the imidazole derivatives, cycloaddition reactions of cycloimmonium ylides to variously dipolarophiles (activated alkenes and alkynes) being one choice $[12,13]$.

\footnotetext{
a Alexandru loan Cuza University of lasi, Faculty of Chemistry, 11 Carol I Bd., lasi 700506, Romania

b Alexandru Ioan Cuza University of lasi, Interdisciplinary Research Institute - CERNESIM Center, 11 Carol I Bd., lasi 700506, Romania,

*Corresponding author: ionelm@uaic.ro
} 
Taking into consideration our expertise in the area of cycloimmonium ylides chemistry [13-21], and with the aim of obtaining new biologically active compounds with imidazole skeleton, we decided to study the reactions of imidazolium ylides with dimethyl acetylenedicarboxylate (DMAD), as a symmetrically activated alkyne.

\section{RESULTS AND DISCUSSION}

A literature survey show that the reactions of imidazolium ylides with activated symmetrically or non symmetrically substituted alkynes occur usually as a typically Huisgen $3+2$ cycloadditions [12, 22-29], leading to the corresponding fused azaheterocycles type II, Scheme 1.

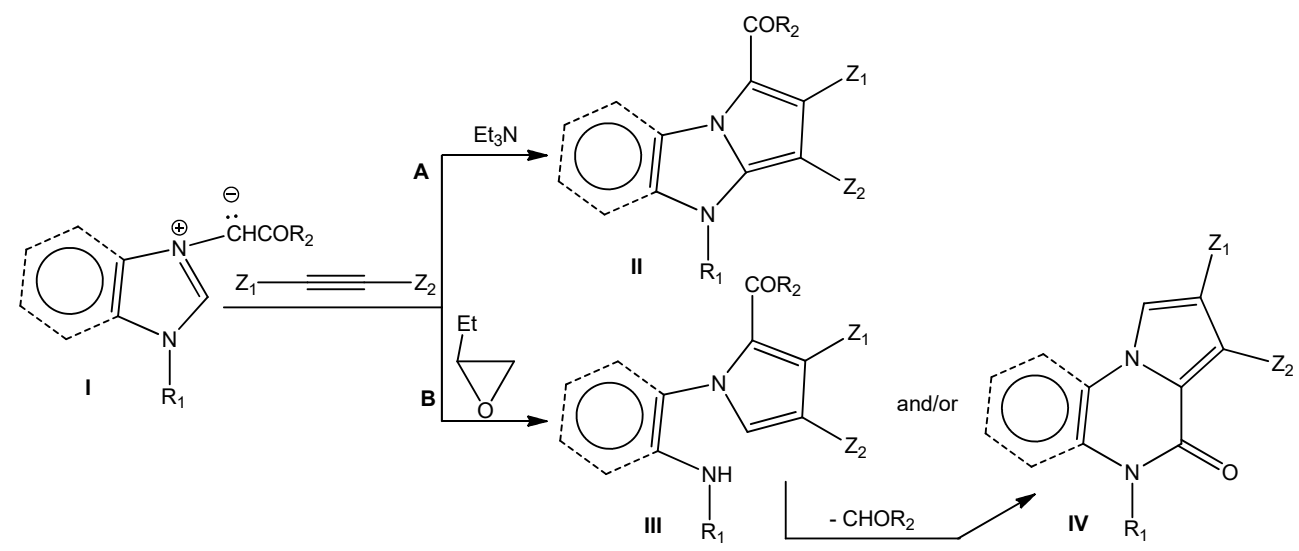

Scheme 1. Reaction pathway of imidazolium ylides I with activated symmetrically or non symmetrically substituted alkynes

However, according with the ylides structure and reaction conditions (in term of solvent and catalyst), the primary cycloaddition could be followed by a ring opening of the imidazole unit from structure II, leading to the pyrrole derivatives type III and/or fused pyrroloquinoxaline IV. Thus, when reaction took place in the presence of triethylamine in nonpolar solvents (usually benzene, pathway A), only azaheterocycles type II are formed, but in very low yields (trace to about 10\%). When reaction took place in 1,2-epoxybutane (used as solvent and as scavenger for hydrobromic acid), the pyrrole derivatives type III and/or fused pyrroloquinoxaline IV are formed [30-34]. 
Having in view the above aspects and with the main aim of increasing the yields of reactions, we decide to study the reactions of imidazolium ylides $\mathbf{2 a - d}$ with $\mathrm{DMAD}$, in polar solvents, using triethylamine as catalyst and hydrobromic acid scavenger. In this respect, pyridine-bis(methylene)-bis(imidazole) ylides $\mathbf{2 a - d}$ (generated in situ from the corresponding imidazolium salts 1a-d, in the presence of triethylamine) were treated with DMAD in methanol, Scheme 2.

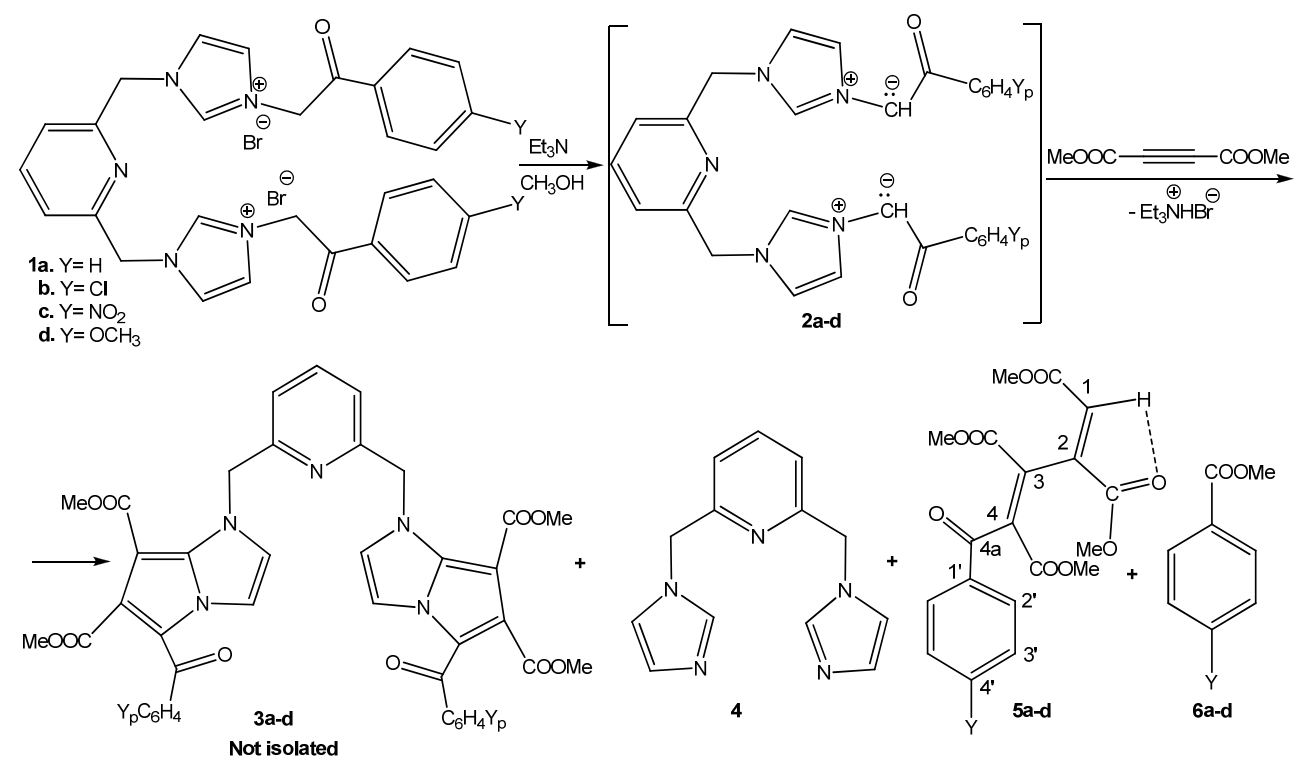

Scheme 2. Reaction pathway of pyridine-bis(methylene)-bis(imidazole) ylides 2a-d with DMAD in polar solvents $(\mathrm{MeOH})$

Surprisingly, instead of the desired azaheterocycles type 3a-d (which are obtained via a 3+2 dipolar cycloaddition reaction), compounds 4-6 are obtained. The formation of 4-6 could be explained by the following reaction mechanism: after the initial formation of ylides 2a-d, a hydrolysis (methanolysis) took place on the ylide bond, with the formation of the 2,6-bis $((1 \mathrm{H}$-imidazol-1yl)methyl) pyridine $\mathbf{4}$ and the unstable carbanion $\mathbf{A}$. 


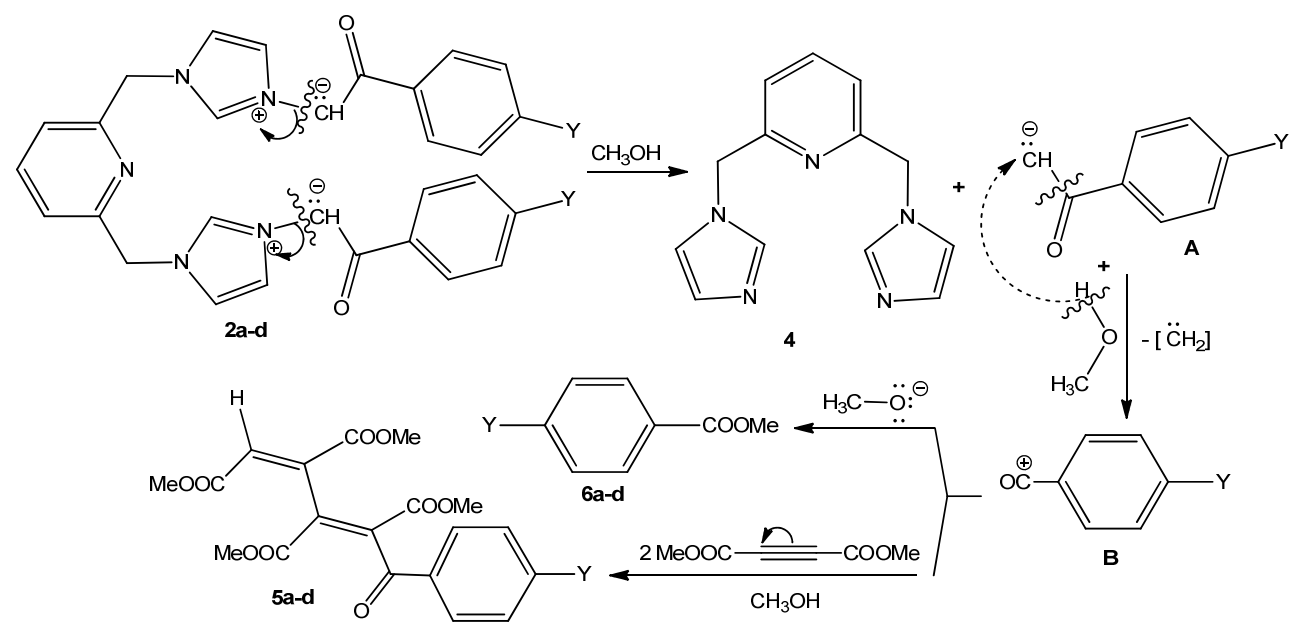

Scheme 3. Reaction mechanism of imidazolium ylides $\mathbf{2 a - d}$ with DMAD in polar solvents $(\mathrm{MeOH})$

The carbanion A react immediately with methanol, eliminate carbene and generate the extremely unstable carbocation $\mathbf{B}$. The stabilisation of cation B could occur in two different ways. One option is to react with the anionic methoxide, leading to the stable 4-Y-benzoate esters 6a-d. In the same time, a competitive and successive reaction of addition of carbocation B to two molecules of DMAD took place, leading to the newly compounds with 1,3-diene structure $\mathbf{5 a - d .}$

The structure of compounds was proven by elemental $(\mathrm{C}, \mathrm{H}, \mathrm{N})$ and spectral analysis (IR, 1H-NMR, 13C-NMR and two-dimensional experiments 2D-COSY, 2D-HMQC, 2D-HMBC). If we consider compound $\mathbf{5 c}$ as representative for the series of compounds with 1,3-diene structure, the most important data furnished by $1 \mathrm{H}-\mathrm{NMR}$ spectrum are the following: the most unshielded proton is the diene one $\mathrm{H}_{1}$ (8.51 ppm, s) because of the powerful deshielding effect exerted by the two carboxymethyl groups from proximity and a possible hydrogen bond with the $\mathrm{CO}$ carbonyl group from the ester unit of the 2 position of diene skeleton (Scheme 2). The aromatic protons from 4-nitrobenzoyl ring appear to $8.29 \mathrm{ppm}\left(\mathrm{d}, J_{3^{\prime} 2^{\prime}}=8.0 \mathrm{~Hz}, \alpha\right.$-nitro, $\beta$-carbonyl) respectively at 7.88 ppm (d, $J_{2^{\prime} 3^{\prime}}=8.0 \mathrm{~Hz}, \beta$-nitro, $\alpha$-carbonyl). The methyl protons (from the four carboxymethyl groups) appear to $3.95 \mathrm{ppm}(6 \mathrm{H}$, from 1 and 4 positions) and $3.59 \mathrm{ppm}(6 \mathrm{H}$, from 2 and 3 positions). In the 13C-NMR spectrum, the most unshielded carbons are those one of carbonyl ketone group which appear at $192.64 \mathrm{ppm}\left(\mathrm{C}_{4 \mathrm{a}}, \alpha\right.$-aryl, $\alpha$-conjugated diene), followed by the carbons of the four carbonyl ester groups at $165.99 \mathrm{ppm}\left(\mathrm{C}_{2}, \mathrm{C}_{3}\right)$ respectively $164.82 \mathrm{ppm}\left(\mathrm{C}_{1}\right.$, 
$\left.\mathrm{C}_{4}\right)$. The carbon atoms from benzene ring appear as follow: $150.78 \mathrm{ppm}\left(\mathrm{C}_{4^{4}}\right)$, $140.72 \mathrm{ppm}\left(\mathrm{C}_{1^{\prime}}\right), 130.63 \mathrm{ppm}\left(\mathrm{C}_{2^{\prime}}\right), 123.04 \mathrm{ppm}\left(\mathrm{C}_{3^{\prime}}\right)$, typical for aromatic para substituted carbons. The four diene carbons appear to $138.42 \mathrm{ppm}\left(\mathrm{C}_{2}\right), 136.04$ ppm $\left(\mathrm{C}_{3}\right), 132.53 \mathrm{ppm}\left(\mathrm{C}_{4}\right), 132.29 \mathrm{ppm}\left(\mathrm{C}_{1}\right)$, in accordance with the proposed structure. At $53.53 \mathrm{ppm}$ and $53.30 \mathrm{ppm}$ appear the two methyl carbons from carboxymethyl groups located in positions 2 and 3 , while at $52.60 \mathrm{ppm}$ and $52.39 \mathrm{ppm}$ appear the two methyl carbons from ester groups located in positions 1 and 4.

Compounds 4 and $\mathbf{6}$, as well as their structures are known from the literature.

\section{CONCLUSIONS}

The reactions pathway of imidazolium ylides with dimethyl acetylenedicarboxylate, in polar solvents, and using triethylamine, were studied. In polar solvents, methanol, a competition between cycloaddition and hydrolysis (methanolysis) reactions took place, the last one prevailing. No cycloaddition reactions have been observed. The reaction mechanism supposes a primary hydrolysis of the ylides on the ylide bond, with the formation of base heterocycle and an unstable carbanion. This carbanion react immediately with methanol and generate an extremely unstable carbocation, which are stabilising itself either reacting with two molecules of DMAD (generating the 1,3-diene compounds 5a-d) either reacting with the anionic methoxide (leading to the 4-Y-benzoate esters 6a-d).

\section{EXPERIMENTAL SECTION}

All the reagents and solvents employed were used without further purification. The nuclear magnetic experiments (1H-NMR, 13C-NMR, 2D-COSY, 2D-HMQC, 2D-HMBC) were recorded using Bruker Avance III 500 spectrometer operating at 500 and $125 \mathrm{MHz}$ for $1 \mathrm{H}$ and respectively $13 \mathrm{C}$ nuclei. The following abbreviations were used to designate chemical shift multiplicities: $s=$ singlet, $\mathrm{d}=$ doublet, $\mathrm{t}=$ triplet. All chemical shifts are quoted on the $\delta$-scale in ppm. Coupling constants are given in $\mathrm{Hz}$. The microanalyses were in satisfactory agreement with the calculated values: $\mathrm{C}, \pm 0.15 ; \mathrm{H}, \pm 0.10 ; \mathrm{N}, \pm 0.30$. Thin layer chromatography (TLC) was carried out on Merck silica gel 60F254 plates. Column chromatography was carried out on silica gel (Roth 60, 0.04-0.063 mm). Visualisation of the plates was achieved using a UV lamp ( $\lambda$ max $=254$ or 365 $\mathrm{nm}$ ). All commercially available products were used without further purification unless otherwise specified. 
DUMITRELA CUCU, VIOLETA MANGALAGIU, DORINA AMARIUCAI-MANTU, VASILICHIA ANTOCI, IONEL I. MANGALAGIU

\section{General procedure for synthesis}

The cycloimmonium salts 1a-d (1 mmol) and dipolarophile (DMAD), ( $2.2 \mathrm{mmol}$ ) were dissolved in $20 \mathrm{~mL}$ of anhydrous methanol. Then triethylamine ( $3 \mathrm{mmol}$ ) was added. The resulting mixture was heated on reflux (with stirring) for 1 hour. The obtained solution was evaporated on vacuum, and the crude product was purified by flash chromatography on silica, using dichloromethane/ methanol 98:2.

(1E,3E)-Tetramethyl-5-oxo-5-phenylpenta-1,3-diene-1,2,3,4-tetracarboxylate, 5a. Yellow oil. FT-IR (KBr) cm${ }^{-1}: 3075,2918,1690,1580,1522,1428.1 \mathrm{H}-\mathrm{NMR}$ $\left(500 \mathrm{MHz}, \mathrm{CDCl}_{3}\right) \delta: 8.50\left(\mathrm{~s}, 1 \mathrm{H}_{1}\right), 7.92\left(\mathrm{~d}, 2 \mathrm{H}_{2}, J=7.2 \mathrm{~Hz}\right), 7.73\left(\mathrm{t}, 1 \mathrm{H}_{4}, J=\right.$ 7.2), $7.61\left(\mathrm{~d}, 2 \mathrm{H}_{3}, J=7.2 \mathrm{~Hz}\right), 3.94\left(\mathrm{~s}, 6 \mathrm{H}: 2 \mathrm{xCH}_{3}\left(\mathrm{COOCH}_{3}\right)\right.$ from 1 and 4 positions), 3.58 (s, $6 \mathrm{H}: 2 \mathrm{xCH}_{3}\left(\mathrm{COOCH}_{3}\right)$ from 2 and 3 positions). 13C-NMR $\left(125 \mathrm{MHz}, \mathrm{CDCl}_{3}\right) \delta: 190.89 \mathrm{C}_{4 a}$ (CO ketone), 165.41 (CO ester from 2 and 3 positions), 164.26 (CO ester from 1 and 4 positions), $138.41 \mathrm{C}_{2}, 136.20$ $\mathrm{C}_{1^{\prime}}, 136.02 \mathrm{C}_{3}, 132.52 \mathrm{C}_{4}, 132.31 \mathrm{C}_{4^{\prime}}, 132.28 \mathrm{C}_{1}, 128.94 \mathrm{C}_{2^{\prime}}, 128.46 \mathrm{C}_{3^{\prime}}$, 55.52 and 53.28 (methyl carbon $\left(\mathrm{COOCH}_{3}\right)$ from 2 and 3 positions), 52.54 and 52.35 (methyl carbon $\left(\mathrm{COOCH}_{3}\right)$ from 1 and 4 positions). Anal. Calcd. for $\mathrm{C}_{19} \mathrm{H}_{18} \mathrm{O}_{9}$ : C, 58.46; $\mathrm{H}, 4.65$; Found: $\mathrm{C}, 58.56$; $\mathrm{H}, 4.60$.

(1E,3E)-Tetramethyl-5-(4-chlorophenyl)-5-oxopenta-1,3-diene-1,2,3,4tetracarboxylate, $\mathbf{5 b}$.

Yellow-brownish oil. FT-IR (KBr) cm-1: 3081, 2922, 1695, 1587, 1552, 1425, 760. 1H-NMR (500 MHz, $\left.\mathrm{CDCl}_{3}\right) \delta: 8.50\left(\mathrm{~s}, 1 \mathrm{H}_{1}\right), 7.96\left(\mathrm{~d}, 2 \mathrm{H}_{3^{\prime}}, J=8.0 \mathrm{~Hz}\right)$, $7.66\left(\mathrm{~d}, 2 \mathrm{H}_{2}, \mathrm{~J}=8.0 \mathrm{~Hz}\right), 3.94\left(\mathrm{~s}, 6 \mathrm{H}: 2 \mathrm{xCH}_{3}\left(\mathrm{COOCH}_{3}\right)\right.$ from 1 and 4 positions), 3.59 (s, $6 \mathrm{H}: 2 \times \mathrm{CH}_{3}\left(\mathrm{COOCH}_{3}\right)$ from 2 and 3 positions). 13C-NMR $\left(125 \mathrm{MHz}, \mathrm{CDCl}_{3}\right) \delta: 189.92 \mathrm{C}_{4 a}$ (CO ketone), 165.26 (CO ester from 2 and 3 positions), 164.18 (CO ester from 1 and 4 positions), $138.76 \mathrm{C}_{4^{\prime}}, 138.40$ $\mathrm{C}_{2}, 136.01 \mathrm{C}_{3}, 132.52 \mathrm{C}_{4}, 132.28 \mathrm{C}_{1}, 132.10 \mathrm{C}_{1^{\prime}}, 130.32 \mathrm{C}_{2^{\prime}}, 129.02 \mathrm{C}_{3^{\prime}}, 55.50$ and 53.26 (methyl carbon $\left(\mathrm{COOCH}_{3}\right)$ from 2 and 3 positions), 52.53 and 52.31 (methyl carbon $\left(\mathrm{COOCH}_{3}\right)$ from 1 and 4 positions). Anal. Calcd. for $\mathrm{C}_{19} \mathrm{H}_{17} \mathrm{ClO}_{9}$ : C, 53.72; $\mathrm{H}, 4.03$; Found: $\mathrm{C}, 53.87$; $\mathrm{H}, 4.13$.

(1E,3E)-Tetramethyl-5-(4-nitrophenyl)-5-oxopenta-1,3-diene-1,2,3,4tetracarboxylate, $\mathbf{5 c}$.

Yellow oil. FT-IR (KBr) cm-1: 3120, 2931, 1698, 1578, 1521, 1470, 1350. 1H$\operatorname{NMR}\left(500 \mathrm{MHz}, \mathrm{CDCl}_{3}\right) \delta: 8.51\left(\mathrm{~s}, 1 \mathrm{H}_{1}\right), 8.29\left(\mathrm{~d}, 2 \mathrm{H}_{3}, \mathrm{~J}=8.0 \mathrm{~Hz}\right), 7.88$ (d, $2 \mathrm{H}_{2}, J=8.0 \mathrm{~Hz}$ ), $3.95\left(\mathrm{~s}, 6 \mathrm{H}: 2 \mathrm{xCH}_{3}\left(\mathrm{COOCH}_{3}\right)\right.$ from 1 and 4 positions), 3.59 (s, $6 \mathrm{H}: 2 \mathrm{xCH}_{3}\left(\mathrm{COOCH}_{3}\right)$ from 2 and 3 positions). 13C-NMR (125 MHz, $\left.\mathrm{CDCl}_{3}\right) \delta: 192.64 \mathrm{C}_{4 a}$ (CO ketone), 165.99 (CO ester from 2 and 3 positions), 
164.82 (CO ester from 1 and 4 positions), $150.78 \mathrm{C}_{4^{\prime}}, 140.72 \mathrm{C}_{1^{\prime}}, 138.42 \mathrm{C}_{2}$, $136.04 \mathrm{C}_{3}, 132.53 \mathrm{C}_{4}, 132.29 \mathrm{C}_{1}, 130.63 \mathrm{C}_{2}, 123.04 \mathrm{C}_{3^{\prime}}, 55.55$ and 53.30 (methyl carbon $\left(\mathrm{COOCH}_{3}\right)$ from 2 and 3 positions), 52.60 and 52.39 (methyl carbon $\left(\mathrm{COOCH}_{3}\right)$ from 1 and 4 positions). Anal. Calcd. for $\mathrm{C}_{19} \mathrm{H}_{17} \mathrm{NO}_{11}$ : C, 52.42; H, 3.94; N, 3.22; Found: C, 52.27; H, 3.84; N, 3.02.

(1E,3E)-Tetramethyl-5-(4-methoxyphenyl)-5-oxopenta-1,3-diene-1,2,3,4tetracarboxylate, $\mathbf{5 d}$.

Pale yellow oil. FT-IR (KBr) cm-1: 3079, 2927, 1682, 1600, 1240, 1161. 1H$\operatorname{NMR}\left(500 \mathrm{MHz}, \mathrm{CDCl}_{3}\right) \delta: 8.49\left(\mathrm{~s}, 1 \mathrm{H}_{1}\right), 8.00\left(\mathrm{~d}, 2 \mathrm{H}_{2}, \mathrm{~J}=8.4 \mathrm{~Hz}\right), 7.12\left(\mathrm{~d}, 2 \mathrm{H}_{3^{\prime}}\right.$, $J=8.4 \mathrm{~Hz}$ ), $3.93\left(\mathrm{~s}, 6 \mathrm{H}: 2 \mathrm{xCH}_{3}\left(\mathrm{COOCH}_{3}\right)\right.$ from 1 and 4 positions $), 3.80(\mathrm{~s}, 3 \mathrm{H}$ from $\left.\mathrm{OCH}_{3}\right), 3.58\left(\mathrm{~s}, 6 \mathrm{H}: 2 \mathrm{CH}_{3}\left(\mathrm{COOCH}_{3}\right)\right.$ from 2 and 3 positions). 13C-NMR $\left(125 \mathrm{MHz}, \mathrm{CDCl}_{3}\right) \delta: 189.10 \mathrm{C}_{4 a}$ (CO ketone), 165.04 (CO ester from 2 and 3 positions), 164.00 (CO ester from 1 and 4 positions), $163.92 \mathrm{C}_{4}, 138.40 \mathrm{C}_{2}$, $136.02 \mathrm{C}_{3}, 132.49 \mathrm{C}_{4}, 132.28 \mathrm{C}_{1}, 130.60 \mathrm{C}_{1^{\prime}}, 126.31 \mathrm{C}_{2}, 114.23 \mathrm{C}_{3^{\prime}}, 55.80$ (carbon from $\left.\mathrm{OCH}_{3}\right), 55.50$ and 53.25 (methyl carbon $\left(\mathrm{COOCH}_{3}\right)$ from 2 and 3 positions), 52.50 and 52.30 (methyl carbon $\left(\mathrm{COOCH}_{3}\right)$ from 1 and 4 positions). Anal. Calcd. for $\mathrm{C}_{20} \mathrm{H}_{20} \mathrm{O}_{10}$ : C, 57.14; $\mathrm{H}, 4.80$; Found: C, 57.04; H, 4.85.

\section{ACKNOWLEDGMENTS}

Funding for this research was provided by UEFISCDI within the project CNFIS-FDI-2019-0129. Authors are also thankful to the POSCCE-O 2.2.1, SMIS-CSNR 13984-901, No. 257/28.09.2010 Project, CERNESIM, for the NMR experiments.

\section{REFERENCES}

1. E. Serrao; Z. L. Xu; B. Debnath; F. Christ; Z. Debyser; Y.Q. Long; N. Neamati; Bioorg. Med. Chem., 2013, 21, 5963-5972.

2. Y. Al-Soud; N. Al-Masoud; E. de Clerck; C. Pannecouque; Acta Pharm., 2007, 57, 379-393.

3. Y.L. Fan; X. H. Jin; Z.P. Huang; H.F. Yu; Z.G. Zeng; T. Gao; L.S. Feng; Eur. J. Med. Chem., 2018, 150, 347-365.

4. A. Campaniço; R. Moreira; F. Lopes; Eur. J. Med. Chem., 2018, 150, 525-545.

5. V. Antoci; D. Cucu; G. Zbancioc; C. Moldoveanu; V. Mangalagiu; D. AmariucaiMantu; A. Aricu; I.I. Mangalagiu; Future Med. Chem., 2019, 11, in press.

6. C.N. Lungu; B.I. Bratanovici; M.M. Grigore; V. Antoci; I.I. Mangalagiu; Curr. Med. Chem., 2019, 26, in press. 
DUMITRELA CUCU, VIOLETA MANGALAGIU, DORINA AMARIUCAI-MANTU, VASILICHIA ANTOCI, IONEL I. MANGALAGIU

7. D. Mantu; V. Antoci; C. Moldoveanu; G. Zbancioc; I.I. Mangalagiu; J. Enzyme Inhib. Med. Chem., 2016, 31(S2), 96-103.

8. A.M. Zbancioc; Ghe. Zbancioc; C. Tanase; A. Miron; C. Ursu; I.I. Mangalagiu; Lett. Drug. Des. Discov., 2010, 7, 644-649.

9. Y.X. Xu; H. Wang; X.K. Li; S.N. Dong; W.W. Liu; Q. Gong; T.D. Wang; Y. Tang; J. Zhu; J. Li; H.Y. Zhang; F. Mao; Eur. J. Med. Chem., 2018, 143, 33-47.

10. P. Molina; A. Tárraga; F. Otón; Org. Biomol. Chem., 2012, 10, 1711-1724.

11. M. Gaba; C. Mohan; Med. Chem. Res., 2016, 25, 173-210.

12. I. Zugravescu; M. Petrovanu; N-Ylid Chemistry, McGraw-Hill, London, New York, 1976, pp. 100-117.

13. I.I. Mangalagiu; I. Druta; M. Constantinescu; I. Humelnicu; M. Petrovanu; Tetrahedron, 1996, 52 (26), 8853-8862.

14. I.I. Mangalagiu; G. Mangalagiu; G. Drochioiu; C. Deleanu; M. Petrovanu; Tetrahedron, 2003, 59, 111-114.

15. M. Caprosu; Ghe. Zbancioc; C. Moldoveanu; I.I. Mangalagiu; Collect. Czech Chem. C., 2004, 69, 426-434.

16. G. Zbancioc; V. Bejan; M. Risca; C. Moldoveanu; I.I. Mangalagiu; Molecules, 2009, 14(1), 403-411.

17. R. Tucaliuc; V. Cotea; M. Niculaua; C. Tuchilus; D. Mantu; I.I. Mangalagiu; Eur. J. Med. Chem., 2013, 67, 367-372.

18. G. Zbancioc; I.I. Mangalagiu; C. Moldoveanu; Ultrason. Sonochem., 2015, 23, 376-383.

19. C.I. Ciobanu; V. Antoci; D. Mantu; I.I. Mangalagiu; Rev. Chim. Bucharest, 2015, 66(4), 497-498.

20. G. Zbancioc; C. Moldoveanu; I. Humelnicu; V. Vasilache; I.I. Mangalagiu; Rev. Chim. Bucharest, 2016, 67(8), 1516-1519.

21. C. Moldoveanu; G. Zbancioc; D. Mantu; D. Maftei; I.I. Mangalagiu; Plos One, 2016, 11 (5), e0156129 (1-9).

22. H. Ogura; K. Kikuchi; J. Org. Chem., 1972, 37, 2679-2682.

23. I. Zugravescu; J.M. Herdan; I. Druta; Rev. Roum. Chim., 1974, 19, 649-658.

24. I. Zugravescu; J.M. Herdan; I. Druta; Rev. Roum. Chim., 1974, 19, 659-664.

25. O. Meth-Cohn; Tetrahedron Lett., 1975, 413-416.

26. B. Wang; J. Hu; X. Zhang; Y. Hu; H. Hu; J. Heterocycl. Chem., 2000, 37, 1533-1537.

27. E. Georgescu; F. Georgescu; C. Roibu; P. C. luhas; C.Draghici; M. T. Caproiu; Rev. Roum. Chim., 2002, 47, 885-891.

28. K. Wu; Q.Y. Chen; Synthesis, 2003, 35-40.

29. X. Fang; Y.X. Wu; J. Deng; S.W. Wang, Tetrahedron, 2004, 60, 5487-5493.

30. A. Nicolescu; C. Deleanu; E. Georgescu; F. Georgescu; A.M. Iurascu; S. Shova; P. Filip; Tetrahedron Lett., 2013, 54, 1486-1488.

31. E. Georgescu; A. Nicolescu; F. Georgescu; F. Teodorescu; D. Marinescu; A.M. lurascu-Macsim; C. Deleanu; Beilstein J. Org. Chem., 2014, 10, 2377-2387.

32. E. Georgescu; A. Nicolescu; F. Georgescu; F. Teodorescu; S. Shova; A.M. Macsim; C. Deleanu; Synthesis, 2015, 47, 1643-1655.

33. E. Georgescu; A. Nicolescu; F. Georgescu; S. Shova; B.C. Simionescu; C. Deleanu; Rev. Roum. Chim., 2016, 61(4-5), 283-290.

34. E. Georgescu; A. Nicolescu; F. Georgescu; F. Teodorescu; S. Shova; A.T. Marinoiu; A.F. Dumitrascu; C. Deleanu; Tetrahedron, 2016, 72, 2507-2520. 